\title{
DETECTION OF AIRBORNE PSYCHROTROPHIC BACTERIA AND FUNGI IN FOOD STORAGE REFRIGERATORS
}

\author{
Sema Sandikci Altunatmaz ${ }^{1 *}$, Ghassan Issa ${ }^{2}$, Ali Aydin ${ }^{3}$ \\ ${ }^{1}$ Food Technology Programme of Vocational High School, Faculty of Veterinary Medicine, Istanbul University, 34320 Avcilar, \\ Istanbul, Turkey; ${ }^{2}$ Culinary Programme. Avrupa Vocational School. Kazlıçeşme İstanbul Turkey; ${ }^{3}$ Department of Food Hygiene \\ and Technology, Faculty of Veterinary Medicine, Istanbul University, Avcilar 34320, Istanbul, Turkey.
}

Submitted: January 25, 2011; Returned to authors for corrections: February 22, 2012; Approved: June 07, 2012.

\begin{abstract}
The purpose of this study was to determine the microbiological air quality (psychrotrophic bacteria and airborne fungi) and distribution of fungi in different types of ready-to-eat (RTE) food-storage refrigerators $(n=48)$ at selected retail stores in the city of Edirne, Turkey. Refrigerators were categorized according to the type of RTE food-storage: meat products, vegetables, desserts, or a mix of food types. Microbiological quality of air samples was evaluated by using a Mas-100 Eco Air Sampler. Four refrigerators (all containing meat products, $8.3 \%$ ) produced air samples with undetectable microorganisms. The highest detected mean value of airborne psychrotrophic bacteria and fungi was $82.3 \mathrm{CFU} / \mathrm{m}^{3}$ and $54.6 \mathrm{CFU} / \mathrm{m}^{3}$, respectively and were found in mixed-food refrigerators. The dominant airborne fungal genera found were Penicillium (29.0\%), Aspergillus (12.0\%), Mucor (9\%), Cladosporium (8\%), Botyrtis (7\%), and Acremonium (6\%). By definition, RTE food does not undergo a final treatment to ensure its safety prior to consumption. Therefore, ensuring a clean storage environment for these foods is important to prevent food-borne disease and other health risks.
\end{abstract}

Key words: Airborne fungi; psychrotrophic bacteria; ready-to-eat food; air sampler; refrigerator

\section{INTRODUCTION}

The microbiological quality of air is very important to ensure the safety and quality of food during both production and storage (5). Airborne microorganisms can arise from many sources including air-conditioning systems, raw materials, and specific food production systems (3) and commonly include the propagules of micro- and macrofungi (31) along with bacteria and their resting spores. Airborne microorganisms can be electrostatic and have been shown to stick to and deposit on surfaces (48) and growth of these organisms can cause contamination in the air of refrigerators via aerosol formation (40). However, the extent to which airborne microorganisms inside food-storage refrigerators contribute to food contamination is largely unknown.

Temperature is an important factor in the growth of microorganisms. The practice of storing food at refrigeration temperature is common for controlling the growth of 
psychrotrophic microorganisms, some pathogens, and maintaining product quality (34). Nevertheless, fungi and psychrotrophic bacteria are commonly associated with spoilage of food at refrigerator temperatures. Fungi predominate in refrigerated food spoilage when low water activity, high acidity or packaging conditions select for their growth over bacteria in foods. Psychrotrophic fungi are also commonly isolated from refrigerated fresh animal products, fruits and vegetables (3), and ready-to-eat foods. Mould genera that have psychrotrophic species include Alternaria, Aspergillus, Botrytis, Cladosporium, Fusarium, Geothricum, Monascus, Mucor, Penicillium, Rhizopus, and Trichothecium. Among the yeast genera involved are Candida, Debaryomyces, Saccharomyces, Torulopsis $(14,24)$. Therefore, determination of levels, types, and persistence of airborne fungi in food storage and processing environments is an important part of hygiene monitoring programmes (37).

Air sampling is useful for monitoring airborne biological agents and can be conducted qualitatively or quantitatively (5). Quantitative methods include active air sampling (impaction technique) and passive air sampling (sedimentation technique) on solid surfaces (3). Active air sampling typically relies upon devices that draw a fixed volume of air at a specific speed over a specific period time for the assessment of viable airborne microorganisms (1) and can collect spores of different sizes (18). Active air sampling is faster and recovers more airborne microorganisms than passive techniques. Additionally, active sampling methods are more sensitive in determining pathogenic contamination in specified areas $(3,40)$. The MAS100 Eco air sampler (Staefa, Switzerland) belongs to a new generation of single stage impactor air samplers. The performance of this sampler for enumeration of viable airborne microorganisms is statistically higher compared with other portable samplers $(16,47)$.

The objectives of this study are to investigate the incidence of airborne fungi flora in different retail food storage refrigerators (meat products, vegetables, dessert and mixed foods) using active air sampling and to determine the association of temperature with the population of psychrotrophic bacteria and airborne fungi.

\section{MATERIALS AND METHODS}

\section{Sampling procedure}

During the period of June and August 2006, 96 petri dishes (48 petri dishes for psychrotrophic bacteria and 48 Petri dishes for airborne fungi) were collected from 48 ready-to-eat food storage refrigerators air of retail stores (restaurants, cafeterias, and buffets) in Edirne, Turkey.

Ready-to-eat food refrigerators included: meat products (salami, sausage, fermented sausage-sucuk, meatball; $\mathrm{n}=12$ ), mixed foods (appetizers, vegetables, dairy products, meat products; $n=26)$, vegetables $(n=6)$, and dessert (baklava, profiterole, keskul, etc.; $\mathrm{n}=4$ ). The ready-to-eat foods were most commonly stored unpackaged and retail stores were selected based on high regional sales. Samples were transported to the laboratory under refrigerated conditions (4$\left.6^{\circ} \mathrm{C}\right)$.

Air from the refrigerators was sampled using a MAS-100 Eco air sampler (Merck, 1.09227). The air sampler was calibrated to sample $100 \mathrm{~L}$ of air per min, and Petri dishes (9 $\mathrm{cm}$ in diameter) were used to intercept a volume of $100 \mathrm{~L}$ of impacted air per sample. The air sampler's lid was first sterilized at $121{ }^{\circ} \mathrm{C} / 15$ minutes and sanitized with $70 \%$ ethyl alcohol, before and after each sampling. The instruction manual provided by the producer was used for the sampling process (2).

\section{Microbial analysis}

The number of psychrotrophic bacteria and airborne fungi were determined with standard plate count agar (Oxoid CM 463, Basingstoke, UK) and Dichloran Rose Bengal Chloramphenicol Agar (DRBC) (Merck 1.00466, Darmstadt, Germany), according to methods proposed by APHA (3). Psychrotrophic bacteria were enumerated after 10 days of incubation at $7^{\circ} \mathrm{C}$ (aerobic) and airborne fungi colonies were 
enumerated after 5 days at $22-25^{\circ} \mathrm{C}$ (3). Colony forming units (CFU) were counted and reported as $\mathrm{CFU} / \mathrm{m}^{3}$ of air sampled.

The average number of bacteria and fungi $\left(\mathrm{CFU} / \mathrm{m}^{3}\right)$ count was determined using the conversion formula recommended by the air sampler manufacturer: $\mathrm{Pr}=\mathrm{N}[1 / \mathrm{N}+1 / \mathrm{N}-1+1 / \mathrm{N}-2 \ldots 1 / \mathrm{N}-$ $\mathrm{r}+1]$, where $\operatorname{Pr}=$ probable statistical total number $(\mathrm{CFU} /$ air volume); $\mathrm{N}=400$ (number of holes in perforated lid of the sampler), and $\mathrm{r}=$ number of CFU counted on the Petri dish (2).

Identification of fungi was determined by macro and micro-morphological characteristics according to taxonomic keys $(25,35,41,42)$.

After the enumeration of moulds, colonies were subcultured on malt extract agar (MEA) [Merck 1.05398 (Darmstadt, Germany)], as recommended by the Second International Workshop on Standardization of Methods for the Mycological Examination of Foods as a medium for use in identifying moulds (21). Plates were incubated at $25^{\circ} \mathrm{C}$ for $5-7$ days.

\section{Temperature analysis}

The internal temperatures of the sampled refrigerators were measured with a digital thermometer (Testo 110, Testo AG, Lenzkirch, Germany), with an accuracy of a $0.2^{\circ} \mathrm{C}$ within the range of -25 to $+75^{\circ} \mathrm{C}$.

\section{Statistical analysis}

One-way ANOVA and Duncan's multiple range tests were used to analyze microbial counts $/ \mathrm{m}^{3}$ air and temperature. Statistical estimations were performed using the Statistical Package for the Social Sciences (44).

\section{RESULTS AND DISCUSSION}

Food-borne disease and food poisoning are common throughout the world. Both of these public health problems and the microbiological spoilage of foods can be minimized by proper storage, the careful choice of raw materials, and proper food preparation (22). Refrigerated foods can become vectors for food-borne illness by contamination with food-borne pathogens in retail stores, processing plants, or consumers' homes (26).

Restaurants, cafeterias, and bars are the most frequently cited origins of food-borne outbreaks (10). In this study, readyto-eat food retail stores were visited and 48 refrigerators were sampled. Of the refrigerators sampled, $42(87.5 \%)$ tested positive for psychrotrophic bacteria or fungi. Only 4 meatcontaining refrigerators $(33.3 \%)$ were found to be free of microorganisms in air samples. This results can be related the good hygiene conditions (cleaning status of refrigerators) of meat containing refrigerators (n: 4). Six out of 48 petri dishes did not detect psychrotrophic bacteria (12.5\%; 4 mixed-foods and 2 vegetable refrigerators) and 6 other Petri dishes did not detect airborne fungi $(12.5 \%$; 4 mixed foods and 2 dessert refrigerators). According to the researchers, psychrotrophic bacteria flora was found dominant in meat containing refrigerators $(6,13)$.

Temperature is one of the major controlling factors of food quality and food safety because of its influence on microbial growth rates. Despite the fact that low temperature can reduce the growth rate of many species of microorganisms, it has been reported that psychrotrophic microorganisms can grow at normal refrigeration temperatures (30). In cooler climates, psychrotrophic bacteria constitute a higher percentage of the microflora than in warmer climates $(6,15)$. Most psychrotrophic bacteria found in food are species of Acinetobacter, Aeromonas, Bacillus, Clostridium, Klebsiella, Esherichia, Lactobacillus, Listeria, Morexella, Pseudomonas, Serratia, Streptococcus etc. (3).

In this study, refrigerators containing a mix of foods had the highest mean value of psychrotrophic bacteria (82.3 $\mathrm{CFU} / \mathrm{m}^{3}$ ) and the lowest mean value was found in dessertcontaining refrigerators (Table 1). In a different study of domestic refrigerators, airborne psychrotrophic bacteria were found in the following distribution: $<200 \mathrm{CFU} / \mathrm{m}^{3}(17.2 \%)$, 200-500 CFU $/ \mathrm{m}^{3}$ (31.0\%), 500-1000 $\mathrm{CFU} / \mathrm{m}^{3}$ (34.6\%), and $>1000 \mathrm{CFU} / \mathrm{m}^{3}$ (17.2\%) (48). However, in our study we found 
$<200 \mathrm{CFU} / \mathrm{m}^{3}$ of psychrotrophic bacteria in all the air sampled.

Refrigerators containing mixed foods also had the highest mean value of airborne fungi $\left(54.6 \mathrm{CFU} / \mathrm{m}^{3}\right)$ (Table 1). This result is consistent with Zickrick et al. (48) that found that $66.5 \%$ of domestic refrigerators in Germany contained $<100 \mathrm{CFU} / \mathrm{m}^{3}$. Yeast and mould counts determined in air samples from food processing areas are higher than those found in this stuy $(5,28,40,43)$.

In this study we found the average mean value of all psychrotrophic bacteria counts were higher than the average mean value of airborne fungi. Conversly, Col (13) found the distribution of yeast and mould higher than aerobic flora $\left(309 \mathrm{CFU} / \mathrm{m}^{3}\right.$ and 229 $\mathrm{CFU} / \mathrm{m}^{3}$, respectively) in air samples of food cold-storage areas in
Turkey.

As shown in Table 2, the moulds isolated from air samples were broadly represented by 17 genera. In total, 172 mould and 4 yeast (Candida krusei) isolates were obtained from 48 samples. Penicillium italicum was the most frequently detected species, found in $12.6 \%$ of 86 air samples, followed by Botrytis cinerea (5.8\%), Mucor rasemosus (5.8\%) and Rhizopus oryzae (5.8\%). Several researchers have reported the frequency of Penicillium, Aspergillus, Mucor and Cladosporium in food processing air samples (5, 28, 40, 43). Additionally, Asefa et al. (5) and Sørensen et al. (43) reported Penicillium spp. as one of most predominant moulds in food processing areas.

Table 1. Mean value of psychrotrophic bacteria and airborne fungi counts and temperature of food storage refrigerators $(\mathrm{n}=48)$

\begin{tabular}{lccc}
\hline Type of refrigerators & $\begin{array}{c}\text { Psychrotrophic bacteria } \\
\mathbf{x} \pm \mathbf{S x}\left(\mathbf{c f u} / \mathbf{m}^{\mathbf{3}}\right)\end{array}$ & $\begin{array}{c}\text { Airborne fungi } \\
\mathbf{x} \pm \mathbf{S x}\left(\mathbf{c f u} / \mathbf{m}^{3}\right)\end{array}$ & $\begin{array}{c}\text { Temperature } \\
\mathbf{x} \pm \mathbf{S x}\left({ }^{\circ} \mathbf{C}\right)\end{array}$ \\
\hline Meat $(\mathrm{n}=12)$ & $\left.48.3 \pm 15.5^{\mathrm{a}}\right)$ & $23.3 \pm 6.4^{\mathrm{a}}$ & $5.3 \pm 0.2^{\mathrm{a}}$ \\
Vegetable $(\mathrm{n}=6)$ & $70.0 \pm 35.2^{\mathrm{a}}$ & $40.0 \pm 9.67^{\mathrm{a}}$ & $6.1 \pm 0.3^{\mathrm{a}}$ \\
Mixed-Food $(\mathrm{n}=26)$ & $82.3 \pm 14.3^{\mathrm{a}}$ & $54.6 \pm 6.8^{\mathrm{a}}$ & $5.9 \pm 0.2^{\mathrm{a}}$ \\
Dessert $(\mathrm{n}=4)$ & $40.0 \pm 11.6^{\mathrm{a}}$ & $35.0 \pm 20.2^{\mathrm{a}}$ & $5.2 \pm 0.2^{\mathrm{a}}$ \\
\hline
\end{tabular}

*Means in a column with the same letters are significantly $(\mathrm{P}>0.05)$ different from one another.

Table 2. Frequency of fungal isolates from different food storage refrigerators' air

\begin{tabular}{|c|c|c|c|c|c|c|}
\hline Genera & Moulds species & Meat & Vegetable & Mixed & Dessert & Total $(\%)(n=172)$ \\
\hline \multirow[t]{4}{*}{ Acremonium } & Acremonium spp. & 2 & & & & $2(1.2 \%)$ \\
\hline & A. charticola & & 2 & 2 & & $4(2.3 \%)$ \\
\hline & A. strictum & 2 & & & & $2(1.2 \%)$ \\
\hline & A. butyric & & & 2 & & $2(1.2 \%)$ \\
\hline \multirow[t]{7}{*}{ Aspergillus } & A. candidus & & 2 & 2 & 2 & $6(3.4 \%)$ \\
\hline & A. flavus & 2 & & & & $2(1.2 \%)$ \\
\hline & A. melleus & & & 2 & & $2(1.2 \%)$ \\
\hline & A. niger & & & 2 & & $2(1.2 \%)$ \\
\hline & A. tamarii & & & 2 & & $2(1.2 \%)$ \\
\hline & A. terreus & & & 2 & & $2(1.2 \%)$ \\
\hline & A. ochraceus & & & 4 & & $4(2.3 \%)$ \\
\hline \multirow[t]{2}{*}{ Botrytis } & B. aclada & 2 & & & & $2(1.2 \%)$ \\
\hline & B. cinerea & & 2 & 8 & & $10(5.8 \%)$ \\
\hline \multirow[t]{3}{*}{ Cladosporium } & Cladosporium spp. & 4 & & 2 & 2 & $8(4.7 \%)$ \\
\hline & C. herbarum & 4 & & & & $4(2.3 \%)$ \\
\hline & C. macrocarpum & & & 2 & & $2(1.2 \%)$ \\
\hline \multirow[t]{2}{*}{ Mucor } & M. racemosus & & & 10 & & $10(5.8 \%)$ \\
\hline & M. plumbeus & & & 6 & & $6(3.4 \%)$ \\
\hline \multirow[t]{6}{*}{ Penicillium } & Penicillium spp. & 2 & 2 & 4 & 2 & $10(5.8 \%)$ \\
\hline & P. digitatum & & & 4 & & $4(2.3 \%)$ \\
\hline & P. expansum & 2 & & 4 & & $6(3.4 \%)$ \\
\hline & P. italicum & 4 & & 18 & & $22(12.6 \%)$ \\
\hline & P. rugulosum & & & 2 & & $2(1.2 \%)$ \\
\hline & P. verruculosum & 2 & & 2 & 2 & $6(3.4 \%)$ \\
\hline
\end{tabular}


Table 2. Continuation

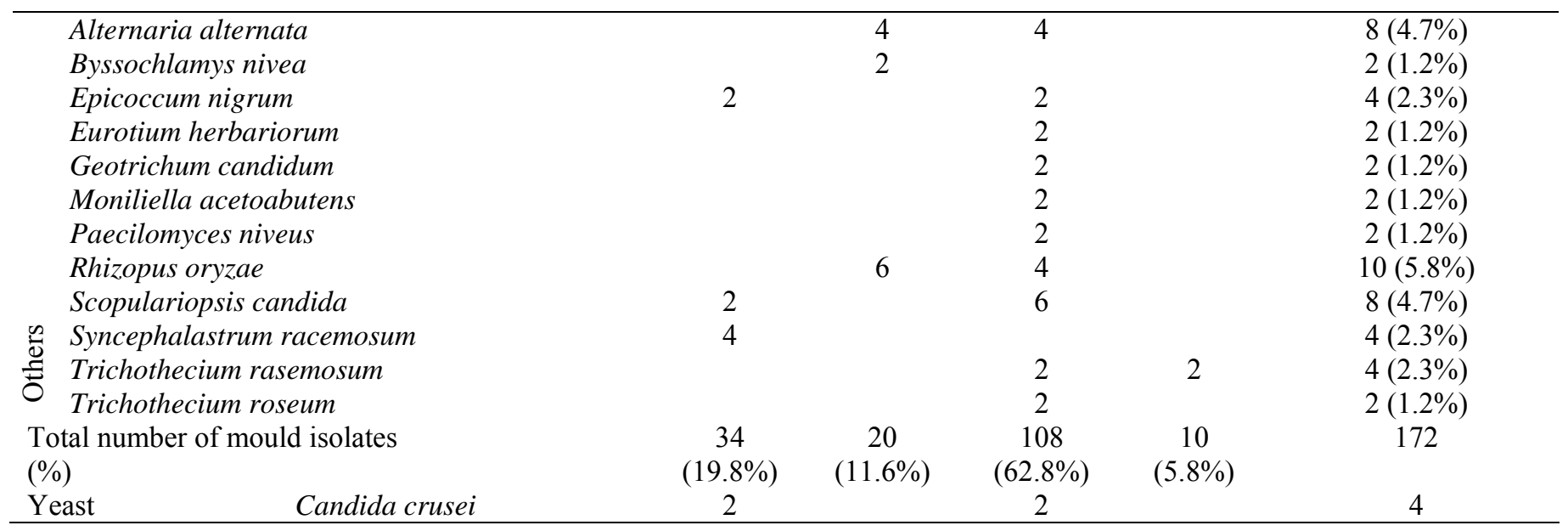

In our study, the dominant airborne fungal genera was Penicillium (29.0\%), Aspergillus (12.0\%), Mucor (9\%), Cladosporium (8\%), Botrytis (7\%), and Acremonium (6\%). Other significant fungi identified were Rhizopus, Alternaria and Scopulariopsis (Figure 1). Other researchers have also reported (4, 8) Penicillium, Aspergillus, Cladosporium and Alternaria as predominant genera in airborne fungi in the city of Edirne.

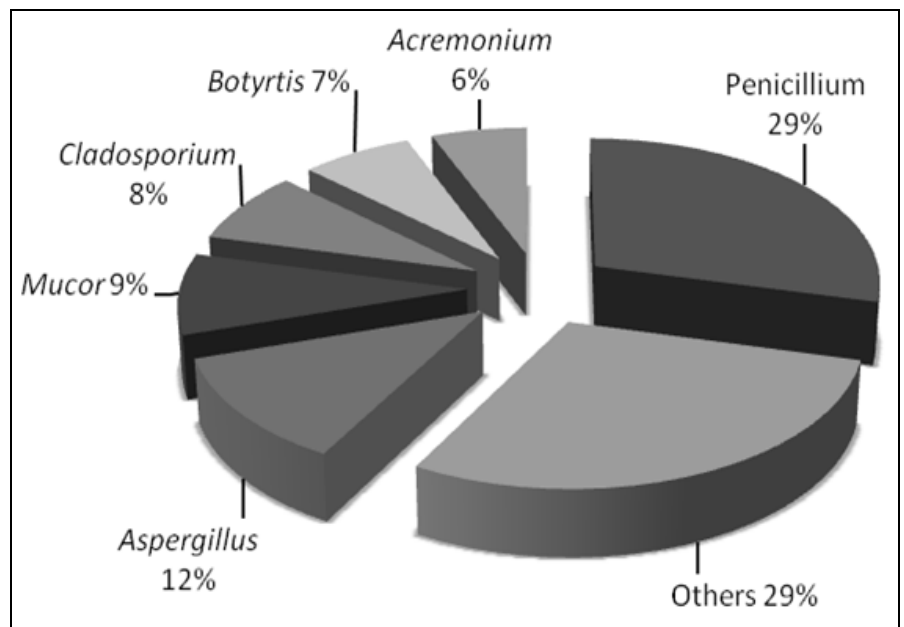

Figure 1. Distribution of mould genera captured by MAS 100 ECO air sampler

Penicillium is isolated frequently from both air and surfaces in food processing areas and was the most frequent genus found in meat and dairy products $(40,43)$. In this study, Penicillium species was detected most commonly in refrigerators containing mixed products (31.4\%) and meat products $(29.4 \%)$. In addition, the dominant species, $P$. italicum, was isolated in mixed-food (81.8\%) and meat refrigerators $(18.2 \%)$. Blue mould, caused by $P$. italicum is among the most economically important postharvest spoilage organisms, which affects fresh vegetables and other foods worldwide (29).

Aspergillus ochraceus, Aspergillus flavus, Aspergillus niger, Aspergillus terreus were the most common species from the Aspergillus genera found in mixed-food refrigerators. These moulds may cause invasive aspergillosis in immunocompromised individuals (16). Additionally, Aspergillus ochraceus is associated with Balkan Endemic Nephropathy (8).

In this study, Mucor racemosus (62.5\%) and Mucor plumbeus (37.5\%) were the dominant species of Mucor genera and are associated with spoilage of cold-stored vegetables, cheese, and meat products (36). We also found Botrytis cinerea, a common spoiler of fruits and vegetables.

Many species of Cladosporium are distributed world-wide and commonly found in air and indoor environments including food processing area $(16,41)$. In our study, Cladosporium species were found in a total of 14 air samples, mainly in refrigerators containing meat $(57.1 \%)$ and mixed-foods 
(28.6\%). Acremonium was also commonly found in meat storage refrigerators (40.0\%). Airborne Cladosporium and Acremonium have been isolated from meat processing areas $(33,43)$, indoors (9), and other food processing areas (23).

Health effects caused by exposure to fungi and the role of fungal metabolites have been the focus of increased attention (38). Various species including Aspergillus and Penicillium genera are often associated with allergic symptoms of the respiratory system (17). Concerns have been raised about exposure to mycotoxin-producing fungi (Aspergillus flavus, A. ochraceus, Aspergillus terreus etc.) in indoor environments, food production area, and food-storage areas. In addition to these genera and species, Alternaria alternata isolated in the present study $(\mathrm{n}=8)$ is a potential mycotoxin producer. Mycotoxin producing fungi commonly found in the air of refrigerators include species of Aspergillus, Penicillium, and Alternaria $(4,8)$. All of these genera were found in our study. Byssochlamys nivea, also found in this study, can produce patulin and has been reported in foods from Turkey (7). Mycotoxin-producing fungi can easily become airborne and mobile and their spores are hazardous to humans and/or animals (32).

Temperature control is important in restraining the growth of psychrotrophic bacteria and pathogenic microorganisms (Listeria monocytogenes, Salmonella sp.) in foods (39). Generally, microbial growth is related with increasing temperature. (45). According to several studies on refrigeration temperatures, a wide percentage of retail and home refrigerators show temperatures above $4^{\circ} \mathrm{C}$, a temperature that prevents most microbial growth and is recommended by many ready-to-eat food producers $(9,11,12,20)$. Similarly, WHO (46) recommended the storage temperature of foods at a maximum of $5{ }^{\circ} \mathrm{C}$ in refrigerator. We also found that the mean temperature of the sampled refrigerators (Meat $=5.3 \pm 0.2$, vegetable $=6.1 \pm 0.3$, mixed foods $=5.9 \pm 0.2$, and dessert $=5.2$ $\pm 0.2)$ was above the recommended temperature. Garrido et al. (19) has reported that a drop in temperature is important to retard the growth of pathogens and other microorganisms within the shelf life of product, especially once the product is purchased and under the responsibility of food producers or consumers.

Ready-to-eat foods are products that do not undergo a final treatment to reduce microbial load before consumption. Therefore, these foods should be stored at the recommended temperature $\left(\leq 4^{\circ} \mathrm{C}\right)$. Even at proper storage temperatures, some spoilage-causing or pathogenic microorganisms grow at low temperatures and lead to reduction of shelf life or affect consumer's health $(27,45)$. In this study, we found that the mean value of psychrotrophic bacteria and airborne fungi was relatively low in air samples taken from refrigerators containing ready-to-eat foods. Even so, many potential allergenic, pathogenic and mycotoxin-producing airborne fungi were found.

Finally, consumers' awareness regarding the microbiological safety of the food is important (11). Many consumers believe that food safety is the responsibility of food manufacturers. This belief has significant implications for public health initiatives to educate and inform the public in matters relating to procuring, storing and preparing food in a microbiologically safe manner.

\section{ACKNOWLEDGEMENTS}

The authors would like to thank Jessica JUST (University of Georgia, College of Agricultural and Environmental Science, Center for Food Safety) is acknowledged for critical reading of the manuscript. This work was supported by the Research Fund of Istanbul University, Project No: BYP-122/13122006.

\section{REFERENCES}

1. Andon, B.M. (2006). Active and passive air (Settle plate) monitoring in routine environmental programs. PDA J. Pharm. Sci. Techno., 60, 350355.

2. Anonymous (2003). Professional Microbial Air Monitoring System for the Microbiological Testing of Air. Operator's Manual MAS- 
$100^{\mathrm{TM}}$.Available at: http://www.instrument.com.cn/download.asp?url... pdf. Accessed 10 August, 2010.

3. APHA (American Public Health Association) (2001). Compendium of methods for the microbiological examination of foods. American Public Health Association, Washington DC.

4. Asan, A.; Sen, B; Sarica, S. (2002). Airborne fungi in urban air of Edirne City (Turkey). Biologia, 57, 59-68.

5. Asefa, D.T.; Langsrud, S.; Gjerde, R.O.; Kure, C.F.; Sidhu, M.S.; Nesbakken T.; Ida Skaar, I. (2009). The performance of SAS-super-180 air sampler and settle plates for assessing viable fungal particles in the air of dry-cured meat production facility. Food Control, 20, 997-1001.

6. Aydin, A.; Colak, H.; Ciftcioglu, G.; Ugur, M. (2006). Changes in microbiological properties of boneless beef in a one-year study. Arch. für Lebensmittelhyg., 57, 50-54.

7. Aydin, A.; Ulusoy, B.; Ergün, Ö. (2005). A Survey on Heat-Resistant Moulds in Drinking Milk, Milk Products and Fruit Juices that Applied Heat Treatment. Arch. für Lebensmittelhyg., 56, 58-61.

8. Aydogdu, H.; Asan, A. (2008). Airborne fungi in child day care centers in Edirne City, Turkey. Environ. Monit. Assess., 147, 423-444.

9. Azevedo, I.; Regalo, M.; Mena, C.; Almeida, G.; Carneiro, L.; Teixeira, P.; Hogg, T.; Gibbs, P.A. (2005). Incidence of Listeria spp. in domestic refrigerators in Portugal. Food Control, 16, 121-124.

10. Borneff, J.; Hassinger, R.; Wittig, J.; Edenharder, R. (1988). Effective hygienic measurements in households today. Zentralbl. Bacteriol. Microbiol. Hyg., 187, 404-413.

11. Breen, A.; Brock, S.; Crawford, K.; Docherty, M.; Drummond, G.; Gill, L.; Lawton, S.; Mankarious, V.; Oustayiannis, A.; Rushworth, G. (2006). The refrigerator safari; An educational tool for undergraduate students learning about the microbiological safety of food. Br. Food J., 108, 487494.

12. Carrasco, E.; Pérez-Rodríguez, F.; Valero, A.; García-Gimeno, R.M.; Zurera, G. (2007). Survey of temperature and consumption patterns of fresh-cut leafy green salads: Risk factors for listeriosis. J. Food Prot., 70, 2407-2412.

13. Col, B.G. (2006). The investigation about microbial load of indoor air in food factories. Istanbul, Turkey, 61p. (M.Sc. Thesis. Instute of Health Science. Istanbul University).

14. Davenport, R.R. (1980). Cold- tolerant yeasts and yeast-like microorganisms. In: Skinner, F.A, Passmore, S.M., Davenport, R.R. (eds). Biology and activities of yeasts, Academic, New York, USA, p. 215-230.

15. Emprey, W.A.; Scott, W.J. (1939). Investigations on chilled beef: Part1microbial contamination acquired in the meat works. Bull. Counc. Sci. Ind. Res. Austr., 126, 43-49.

16. Engelhart, S.; Glasmacher, A.; Simon, A.; Exner, M. (2007). Air sampling of Aspergillus fumigatus and other thermotolerant fungi: Comparative performance of the Sartorius MD8 airport and the Merck
MAS-100 portable bioaerosol sampler. Inter. J. Hyg. Environ. Health, 6, 733-739.

17. Fischer, G.; Dott, W. (2003). Relevance of airborne fungi and their secondary metabolites for environmental, occupational and indoor hygiene. Arch. Microbiol., 179, 75-82.

18. Flannigan, B. (1997). Air sampling for fungi in indoor environments. $J$. Aerosol Sci., 28, 381-392.

19. Garrido, V.; García-Jalón, I.; Vitas, A.I. (2010). Temperature distribution in Spanish domestic refrigerators and its effect on Listeria monocytogenes growth in sliced ready-to-eat ham. Food Control, 21, 896-901.

20. Godwin, S.L.; Chen, F.; Chambers, E.I.V.; Coppings, R.; Chambers, D. (2007). A comprehensive evaluation of temperature within home refrigerators. Food Prot. Trends, 27, 16-21.

21. Hocking, A.D.; Pitt, J.I.; Samson, R.A.; King, A.D. (1992). Recommendations from the closing session of SMMEF II. In: Samson, R.A., Hocking, A.D., Pitt, J.I., King, A.D. (eds) Modern methods in food mycology. Elsevier, Amsterdam, p. 359-364.

22. Irkin, R. (2010). Determination of microbial contamination sources for use in quality management of cheese industry: "Dil" cheese as an example. J. Verb. Lebensm., 5, 91-96.

23. Ismail, M.A.; Abou-Elala, A.H; Nassar, A.; Michail, D.G. (1995). Fungal contamination of beef carcasses and the environment in a slaughterhouse. Food Microbiology, 12, 441-445.

24. Jay, M.J. (1996). Modern food microbiology. Chapman and Hall, New York, USA.

25. Klich, M.A. (2002). Identification of common Aspergillus species. Centralbureau voor Schimmecultures, Utrecht.

26. Kosa, K.M.; Cates, C.S.; Karns, S.; Godwin, S.L.; Chambers, D. (2007). Consumer home refrigeration practices: Results of a web-based survey. J. Food Prot., 70, 1640-1649.

27. Krämer, J. (2002). Lebensmittelmikrobiologie. Eugen Ulmer Verlag, Stuttgart.

28. Kure, C.F.; Borch, E.; Karlsson, I.; Homleid, J.P.; Langsrud, S. (2008) Use of the selective agar medium CREAD for monitoring the level of airborne spoilage moulds in cheese production. Int. J. Food Microbiol., 122, 29-34.

29. Long, C.A.; Wu, Z.; Deng, B.X. (2005). Biological control of Penicillium italicum of citrus and Botrytis cinerea of grape by Strain 349 of Kloeckera apiculata. Eur. Food Res. Technol., 221, 197-201.

30. Marklinder, I.M.; Lindblad, M.; Eriksson, L.M.; Finnson, A.M.; Lindqvist, R. (2004). Home storage temperatures and consumer handling of refrigerated foods in Sweden. J. Food Prot., 67, 2570-2577.

31. Medrela-Kuder, E. (2003). Seasonal variations in the prevalence of culturable airborne fungi in outdoor and indoor air in Cracow. Int. Biodeterior. and Biodegrad., 52, 203-205.

32. Menetrez, M.Y.; Foarde, K.K. (2004). Emission exposure model for the 
transport of toxic mold. Indoor Built Environ., 13, 75-82.

33. Mizáková, A.; Pipová, M.; Turek, P. (2002). The occurrence of moulds in fermented raw meat products. Czech J. Food Sci., 20, 89-94.

34. Pal, A.; Labuza, T.P.; Diez-Gonzalez, F. (2008). Shelf life evaluation for ready-to-eat sliced uncured turkey breast and cured ham under probable storage conditions based on Listeria monocytogenes and psychrotroph growth. Int. J. Food Microbiol., 126, 49-56.

35. Pitt, J.I. (1979). The genus Penicillium and it's telemorphic states Eupenicillium and Talaromyces. Academic, London.

36. Pitt, J.I.; Hocking, A.D. (2009). Fungi and food spoilage- 3rd edn. Springer, Heidelberg.

37. Portnoy, J.M.; Barnes, C.S.; Kennedy, K. (2004). Sampling for indoor fungi. J. Allergy Clin. Immunol., 113, 189-198.

38. Ren, P.; Jankun, T.M.; Belanger, K.; Bracken, M.B.; Leaderer, B.P. (2001). The relation between fungal propagules in indoor air and home characteristics. Allergy, 56, 419-424.

39. Rybka-Rodgers, S. (2001). Improvement of food safety design of cookchill foods. Food Res. Int., 34, 449-455.

40. Salustiano, V.C.; Andrade, N.J.; Brandão, S.C.C.; Azeredo, R.M.C.; Lima, S.A.K. (2003). Microbiological air quality of processing areas in a dairy plants as evaluated by the sedimentation technique and a one-stage air sampler. Braz. J. Microbiol., 34, 255-259.
41. Samson, R.A.; Hoekstra, E.S.; Frisvad, J.C.; Filtenborg, O. (2002). Introduction to food- and airborne fungi 6 edn. Centraalbureau voor Schimmelcultures, Utrecht.

42. Samson, R.A.; Pitt, J.I. (2000). Integration of modern taxonomic methods for penicillium and aspergillus classification- 4th edn. Harwood, Amsterdam.

43. Sørensen, L.M.; Jacobsen, T.; Nielsen, P.V.; Frisvad, J.C.; Koch, A.G. (2008). Mycobiota in the processing areas of two different meat products. Int. J. Food Microbiol., 124, 58-64.

44. SPSS (1997). SPSS Professional statistics 7.5. SPSS, Chicago.

45. Ugur, M.; Nazli, B.; Bostan, K. (2001). Food Hygiene. Teknik publishing, Istanbul.

46. World Health Organization (2007). Safe preparation, storage and handling of powdered infant formula guidelines. World Health Organization, Geneva.

47. Yao, M.; Mainelis, G. (2007). Analysis of portable impactor performance for enumeration of viable bioaerosols. J. Occupational and Environ. Hyg., 4, (7), 514-524.

48. Zickrick, V.K.; Wittenberg, U.; Kiewel, S. (1995). Beitrag zum mikrobiellen Status der inneren Oberflächen und der luft von Haushaltskühlschränken. Archiv Lebensmittelhyg., 46, 50-54. 